\title{
Risk Based Tax Audit Practices in Ethiopia, Evidence from Western Addis Ababa Small Taxpayers Branch Office
}

\author{
Tesema Gemeda \\ Addis Ababa Revenue Authority \\ Teklu Kassu (PhD) \\ Ethiopian Civil Service University
}

\begin{abstract}
This study was study was designed to assess Practices of Risk Based Tax Audit in Western Addis Ababa Small Taxpayers Branch Office in Ethiopia To achieve the stated objectives descriptive research design with mixed research approach was adopted. The result of the study revealed that there was a significant problem of supporting the audit work by Information Technology, the tax audit evidence is not obtained from y third party. No difference in risk selection criteria's for similar for Large, Medium and Small taxpayers, focusing on revenue collection than enhancing tax compliance, extensive application of comprehensive audit than risk based sample among others The study recommends: adequate use of information Technology in selecting taxpayers based associated risks, emphasizing on spot/issue oriented audits, applying different selection criteria based on their nature, to focus on issue audit and to use third party audit evidence.
\end{abstract}

Keywords: Tax, Risk based Tax Audit, taxpayer selection, Third party information d information Technology DOI: $10.7176 / \mathrm{EJBM} / 12-28-06$

Publication date:October $31^{\text {st }} 2020$

\section{Introduction}

Taxation is the earliest and most common form of government intervention with the economic life of individuals and business enterprises (Clement et al, 2018). However, the potential amount of revenue that any country can raise depends in part on the effectiveness of its tax audit practice. Tax audit is set of activities performed by tax auditors to determine a taxpayer's correct tax liabilities for a particular tax period (OECD, 2006). Risk-based tax audit is more efficient and effective to manage scarce audit resources wisely, target high-risk taxpayers, and assess efficient tax revenue (World Bank, 2011; ERCA, 2010). It is not possible for tax offices to identify the likely taxevaders by random selection and/or manual screening methods. The best cost effective option for both taxpayers and tax office is setting possible indications of risky taxpayers from the available data.

Effective tax audit practice starts from having good risk selection criteria and effective risk selection practices. There are three main organizational requirements for implementing effective risk-based tax audits within a tax organization: resources, administrative structure, and cooperation (World Bank, 2011). However, the tax audit in Ethiopia is challenged by lack of technically competent and Proficient human resource, low data quality, poor intelligence inputs, weak risk based taxpayer selection practice, negative attitude towards taxpaying practices among taxpayers, low incentives for compliant taxpayers and, inconsistency and frequent changes of tax laws (Getaneh, 2011; Kidist, 2016; Ephrem, 2017; Mekonen, 2018; Tesfaye, 2018). Further, the tax audit practiced in Ethiopia shows low performance in terms of quality, tax yield and revenue yield (MoR, 2019; Mekonen, 2018; Kidist, 2016). However, in Ethiopia, no study was conducted to measure the quality of tax audit practiced in terms of tax appeal decisions and there is no study carried out in Ethiopia, Specifically the branch office focusing on Risk based tax audit practices.

In the context of the above statements, this paper was assessed the practices of risk based tax audit in Western Addis Ababa small taxpayer's branch office to assist in creating effective risk based tax audit practice. The study emphasizes on examining the availability of tax audit resources, case selection methods used; types of tax audit frequently performed and tax yield by tax types and business sectors. The next section of the paper presents the statement of the problem and other introductory issues followed by literature review. Then after, the research methods employed was outlined and the results of the study were presented. Finally, important theoretical and practical implications in the area of risk based tax auditing were raised, along with suggestions for future research.

\section{Statement of the Problem}

This study was designed to assess practices of risk based tax audit in Western Addis Ababa branch of Ethiopia, in order to enhance its effectiveness and the taxation system. Even though, the increment of tax revenue collection in absolute terms is undeniable fact, the low performance of Tax to GDP ratio of Ethiopia (12.2\%) remains untouched (Neway et al, 2018, Cephus, 2019). Studies show Ethiopia has lost at least 3.2 billion USD in 2014, which should have been collected from taxes, due to tax evasions and other factors (UNDP, 2016). To limit taxpayers' evasion, governments use the deterrence (audits, financial penalties, and confinement) and non- 
deterrence measures (Clement et al, 2018). One factor that significantly contributes to tax evasion in Ethiopia is lack of apt risk management and effective tax audits practices. However conducting successful and cost-effective audits is not easy task.

Tax audit is among the most effective deterrence measures in tackling tax evasions, raising additional revenue, and lowering future noncompliance (MoR, 2019). Lack of technology based tax information system may result in a possibility of selecting of an honest taxpayer and failure to take up the potential under-reporter; that is costly to both tax administration and the taxpayers (Mukhtar Abdi Elmi et al, 2015). Further, lack of sufficient capacities in tax administrations reduces the probability of detection that again influences the taxpayer's decision concerning whether to evade (World Bank, 2011). There are number of challenges regarding to risk based tax audit practice in Ethiopia that leads to low tax compliance and not yet resolved.

Currently few researches have tried to investigate the status of tax audit practices, tax audit challenges, and tax audit revenue performance (Getaneh, 2011; Netsanet and Chinniah, 2014; Kidist, 2016; Mekonnen, 2017; Belay, 2018; Tesfaye, 2018; Solomon, 2019). However, as far as the researcher's knowledge is concerned, there was no study conducted on risk-based tax audit practices in Ethiopia, and none of the studies examined additional tax audit assessments by business sector and tax types. The above tax audit challenges and the research gap initiated the researcher to fill the gap in this area. Therefore, the intent of this study was to examine risk based tax audit practices in Ethiopia, and suggest for successful audit program that is capable to detect and prevent loss of tax revenue, and increase taxpayers' voluntary compliance.

\section{Objectives}

The main objective of the study was to assess practices of risk based tax audit in Ethiopia from the perspective of $\mathrm{W} / \mathrm{A} / \mathrm{A} / \mathrm{S} / \mathrm{T} / \mathrm{P} / \mathrm{B} / \mathrm{O}$ specifically to,

1. Assess the status of tax audit resources in the study area

2. Review risk based case selection practice of the $\mathrm{W} / \mathrm{A} / \mathrm{A} / \mathrm{S} / \mathrm{T} / \mathrm{P} / \mathrm{B} / \mathrm{O}$

3. Examine tax audit types mostly practiced and additional tax audit assessments by tax types and business sectors

\section{Literature review}

Tax differs from other compulsory payments like charges and other levies in that the taxpayers receives nothing different from non taxpaying members of the same society. Tax audit has been described as the procedure of examining the degree to which the taxpayer has properly prepared the financial statements according to the existing tax laws and whether he/she has correctly reported the tax liabilities (Biber, 2010). Tax audit differs from other audits since only government or its agents do it and its direct goal is collecting revenue to cover government expenditures (Kricher, 2008, MoR, 2019). Tax audit increases the tax revenue, detect taxpayers who fail to fulfill tax obligation, and would impose penalty and fines.

Resources are the backbone of any organization since without input one cannot expect output and human resource is the most important enabler for tax administrations effectiveness. In addition to the required core capabilities, greater attention and emphasis should be given for soft skills and other attributes of the auditors. Specialized coaching and mentoring services are made available to new and existing tax auditors, if desired, in a number of countries (OECD, 2006). To have effective resource management, risk-based selection practice is increasingly used by tax administrators that can be implemented in many different settings and for different types of taxes and, at very low cost compared to the gains in revenue (Marshall and Pomeranz, 2013).

Major tax audit practiced in Ministry of Revenue are desk audit, field audit, advisory audit, record keeping audit, refund audit, issue-oriented audit, comprehensive or full audit and fraud investigation(MoR,2019). According to ERCA Tax audit policy (2010), tax audit practiced should be 50-60\% spot or issue audit, and only 5-10\% comprehensive audit. IMF (2015) study on the other hand shows lower income countries conduct more comprehensive audit (53\%), followed by issue-oriented audit (28\%) and desk audits (19\%). However, too many narrowly focused tax audit(spot, issue tax audit) provides a high level of audit coverage but may result in low audit quality, low tax revenue, and missed opportunities to properly detect taxpayer's noncompliance (OECD, 2006).

Many scholars examined tax audit practice in both developed and developing countries. In Ethiopia, Getaneh (2011) studied tax audit practice (the case of federal government) and concluded the Tax audit program remains undeveloped with an emphasis on comprehensive audit and merchandising sector was mostly selected for tax audit. Netsanet and Chinniah (2014) also concluded Taxpayers are selected for audit based on risk criteria, but similar time and audit techniques was applied for all taxpayers. In addition, the study by Mekonen (2017) also examined challenges of tax audit administration in Addis Ababa evidence from small taxpayer branches and concluded absence of compliance risk-based case selection strategy, scarcity of audit resources, lack of appropriate monitoring and evaluation methods and absence of proficient and experienced tax auditors. Similarly Tesfaye(2018) revealed there is no well-established strategies that make Tax Auditors competent and efficient on their job through training on continuous bases and Belay (2018) also assessed the practices and challenges of tax 
audit and revealed that comprehensive tax audit was repetitively performed tax audit type and the tax audit practice.

\section{Research Methodology}

The study adopts mixed method approach in order to achieve the research objectives and to answer research questions. It employed both quantitative and qualitative approaches. The population consists of all the 62 risk based tax auditors and 10 team leaders. Since the target population is small in number, the researcher chose the census method for data collection than sampling technique. Data was collected using semi-structured questionnaire that was administered to risk based tax auditors and a face-to-face interview was conducted to the risk based audit team leaders. A questionnaire was designed according 5-point Likert scales ranging from strongly agree up to strongly disagree. Secondary data were obtained from tax department annual performance reports and selected risk based audit reports. Further, one hundred thirty five risks based tax audit cases were selected by multi stage sampling from the recent five years (2014/15-2018/19) tax audit reports. The researcher was applied descriptive analysis using Statistical Package for the Social Sciences (SPSS) Version 22 and interpreted the detailed information about each variable quantitatively based on the descriptive model.

\section{Findings, Discussions \& Analysis}

In this chapter, the results of the study was presented, discussed, analyzed, and interpreted. The main aim of the study was to assess risk based tax audit practices from the tax auditors and team leaders' perception. From the total 59 Questionnaires distributed to risk based tax auditors, the response rate $88 \%$ was reasonably good (Yesegat, 2008). Of the ten risk based tax audit team leaders, eight were interviewed and research findings were presented and one hundred twenty five tax audit reports were included for analysis.

\subsection{Background Information of the Respondents}

The gender information shows majority of the respondents were females (57.7\%) indicating the high involvement of female in the study. Further, the result could indicate the composition of the gender in the branch that makes more number of female tax auditors probably due to females' low rate of job turnover, much low rates of disciplinary action; and females' affirmative action during promotion and recruitment (ERCA, 2010). Majority of the respondents $(55.8 \%)$ are below 31 years that shows the branch office have young and energetic workforce that can easily adapt to the changing circumstances of taxation and auditing.

\subsection{Tax Audit Resources}

The first objective of the study was to assess resources available for performing effective risk based tax audit in the branch office.

Table 6.1: Assessment of Material Resource for Tax Audit

\begin{tabular}{|c|c|c|c|c|c|c|c|c|}
\hline No & Statements & 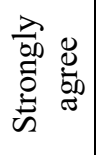 & 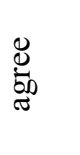 & 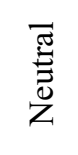 & 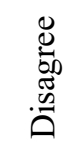 & 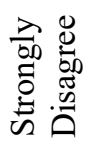 & 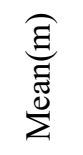 & Dृ: \\
\hline 1 & $\begin{array}{l}\text { There are well organized structure and } \\
\text { conducive working environment for the tax } \\
\text { audit practice }\end{array}$ & 5.8 & 28.8 & 28.8 & 30.8 & 5.8 & 2.99 & 1.04 \\
\hline 2 & $\begin{array}{l}\text { There are enough materials and equipments } \\
\text { required for tax audit practice }\end{array}$ & 9.6 & 32.7 & 17.3 & 32.7 & 7.7 & 3.03 & 1.17 \\
\hline 3 & $\begin{array}{l}\text { There are adequate IT infrastructures (digital } \\
\text { devices, internet facility, system operation, data } \\
\text { base) for tax audit practice- }\end{array}$ & 1.9 & 13.5 & 13.5 & 50.0 & 21.2 & 2.25 & 1.00 \\
\hline 4 & $\begin{array}{l}\text { Tax audit is usually supported by intelligence } \\
\text { input and information from third parties }\end{array}$ & 5.8 & 23.1 & 23.1 & 42.3 & 5.8 & 2.80 & 1.04 \\
\hline 5 & $\begin{array}{l}\text { Continuous and sufficient trainings for tax } \\
\text { auditors is available }\end{array}$ & - & 17.3 & 23.1 & 48.1 & 11.5 & 2.78 & 0.99 \\
\hline 6 & $\begin{array}{l}\text { The branch has adequate experienced and } \\
\text { competent audit staff }\end{array}$ & - & 15.4 & 36.5 & 48.1 & - & 2.67 & 0.73 \\
\hline & overall mean and standard deviation & & & & & & 2.77 & 1.04 \\
\hline
\end{tabular}

Source: Field survey, 2020

Table 6.1 above shows the tax audit functions have enough material and equipments required for effective tax audit practice, but faced problem in having adequate IT infrastructures. As per the questionnaires results indicated that most $(30.8 \%)$ of the respondents disagreed that the branch has well-organized structure and 
conducive working environment for tax audit practice with a mean $2.99(\mathrm{SD}=1.04)$. This shows the branch should consider improving the working environment and organizational structure of the tax audit department since establishing good working conditions is a further part of human resources management to attract and retain high competence staff. Further, most (42.3\%) of the respondents perceived there are enough material resources and equipments for the tax audit. Intelligence information and third party cooperation are the other audit resources. However, only $28.9 \%$ of the respondents have agreed with the statement tax audit practiced have been usually supported by intelligence input and information from third parties. This result was similar with the study that concluded the Hawasa city audit work was not supported by intelligence and third party information (Netsanet and Chinniah, 2014).

Professional and well-trained employees are the most important resource for any modern tax administration and there is a positive relation between training and employee performance Ghafoor \& Aslam, 2011). However, $48.1 \%$ of the respondents just disagreed to the statement continuous, sufficient trainings for tax auditors are available in the branch office, and $11.5 \%$ strongly disagreed. The study revealed also that two-third $(67.31 \%)$ of the respondents didn't attended tax audit trainings before they engaged in the audit practice, that is against ERCA tax audit policy (2010). The interview result sustain the above findings since the branch office has a problem of unskilled auditors and even the capacity building trainings given focus only on tax laws and legislations ignoring the soft skill and techniques required of an auditor.

With regard to human resources, most of the respondents $20(38.5 \%)$ had a work experiences of 2-4 years and only $19.2 \%$ of the respondents have a work experiences for more than six years. This shows that, the branch have less experienced auditors that could negatively affect its performance. It takes time for less experienced auditors to adopt with the taxation system and perform the audit works in efficient manner since auditing needs additional skills like statistical knowledge, communication approach, and research and analysis. The findings are similar to Solomon (2019) and in contrast to Kidist (2016) that concluded 57.14\% of the respondents have less than two years experience. The findings imply need to retain experienced auditors in order to enhance tax audit effectiveness. The overall mean is below average $(\mathrm{M}=2.77, \mathrm{SD}=1.04)$ indicating the branch office was failed in providing adequate resource for tax audit practices and strong attention of all concerned bodies for its improvements that is in-line with study of Kidist (2016) and, Netsanet and Chinniah (2014).

\subsection{Risk Based Tax Audit Case Selection practice}

One of the most important tax audit practice is tax audit cases selection practices. The effectiveness of tax audit practice starts from having effective risk selection criteria's, sufficient information to select high-risk taxpayers and competent staff to analyze the taxpayers risk results (World Bank, 2011). According to interview result with risk selection team leader, tax audit cases selection and practice are separated, considering the existence of Sister Company as criteria is not important for small tax payers branch office, and considering taxpayers who declared high turnover as high risk could discourage compliant and successful taxpayers leading to tax avoidance. The interview result further indicated that the risk selection criteria need continuous reshape to the economic system of the country since one risk criteria might not work at another economic and political conditions.

In words of one audit team leader, "most of the criteria's are assumptions and must be tested empirically. In my audit experience those files selected as high risk have no better additional tax assessments than tax auditees with medium risk." As the documentary evidences and interview results showed, risk assessment selection criteria is similar for LTO, MTO, STO; and some of the criteria could be irrelevant for some branches. In the same way majority of the audit team leaders interviewed perceives the risk selection criteria are not effective and taxpayers are not aptly selected using risk criteria in the branch office. 
Table 6.2: Overview of Risk selection practice in the branch office

\begin{tabular}{|c|c|c|c|c|c|c|c|c|}
\hline No & Statements & 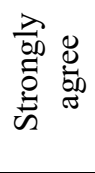 & $\underset{\mathscr{d}}{\mathscr{\Xi}}$ & 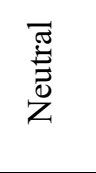 & 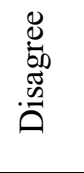 & 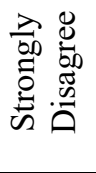 & 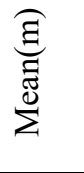 & 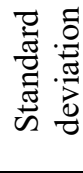 \\
\hline 1 & $\begin{array}{l}\text { Taxpayers risk management department } \\
\text { have competent team for selecting the } \\
\text { audit cases }\end{array}$ & 9.6 & 30.8 & 32.7 & 19.2 & 7.7 & 3.15 & 1.09 \\
\hline 2 & $\begin{array}{l}\text { Case selection is supported by } \\
\text { intelligence \& third party information }\end{array}$ & - & 21.2 & 32.7 & 32.7 & 13.5 & 2.61 & 0.97 \\
\hline 3 & $\begin{array}{l}\text { Last audit with no tax liability was not } \\
\text { selected for the next audit. }\end{array}$ & 5.9 & 15.7 & 15.70 & 35.3 & 15.70 & 2.75 & 1.22 \\
\hline 4 & $\begin{array}{l}\text { High tax potential was not valued more } \\
\text { than other risk criteria's }\end{array}$ & 11.5 & 21.2 & 26.9 & 26.9 & 13.5 & 2.9 & 1.22 \\
\hline \multirow[t]{2}{*}{5} & $\begin{array}{l}\text { The branch is effective in selecting high } \\
\text { risk taxpayers }\end{array}$ & 7.7 & 25 & 21.2 & 32.7 & 13.5 & 2.8 & 1.18 \\
\hline & overall mean and standard deviation & & & & & & 2.84 & 1.13 \\
\hline
\end{tabular}

Source: Field survey, 2020

As depicted in table 6.2 above, most respondents $(40.4 \%)$ perceived the taxpayers risk management department has competent team for selecting the audit cases (mean, 3.15; SD=1.09). However, one third of the respondents remained neutral and the interview with the risk selection team showed the team lacks experience and adequate trainings. The result also showed the case selection of the branch is not supported by intelligence input and information from third parties (percent, 32.7\%; Mean, 3.00; $\mathrm{SD}=1.09$ ) which is evidenced by interview result that is in line with Netsanet and Chinniah(2014). Tax audit without intelligence studies and third party information couldn't enable the tax auditor to detect non compliant taxpayers. Furthermore, more than half (51\%) of respondents with mean of $2.75(\mathrm{SD}=1.22)$ responded that last audit with no tax liability was selected for the next audit. This means there is more chance of some taxpayers to be repetitively audited that was costly for both taxpayers and tax office and against OECD (2006) that stated, an auditee with no additional taxes owed should be granted relief from audit for the next two years except if substantial changes take place by the auditee such as serious tax fraud.

The other question was whether high tax potential was valued more than other risk selection criteria's during taxpayers selection for audit. As a result, according to majority (40.4\%) of the respondents with mean of 2.9 $(\mathrm{SD}=1.22)$ responded the branch values tax potential more than other risk criteria. The result was in agreement with team leaders' in-depth interview result that uncovers assignment of audit files starting from high transaction regardless of its risk level, though the team leaders perceived the risk selection was not focusing on taxpayers with tax potential. From the annual performance reports reviewed, it was observed that the branch selects taxpayers with high turnover by committees in addition to risk files to achieve annual revenue plans. Besides, there was instances where the taxpayers selected by the committee are preferred than the risk selected files. The finding is similar with Belay (2018) that concluded the primary purpose of the tax audit in the office was not ensuring the tax compliance behavior but increasing tax revenue collection.

However, studies show tax payers risk level is positively correlated with the percentage increase in tax collected and the branch should value taxpayers compliance risk than tax potential (Ngui, 2010). Further, most $46.2 \%$ (mean=2.8, $\mathrm{SD}=1.18$ ) of the respondents perceived the branch was not effective in selecting high-risk taxpayers for tax audit. The risk selection leader complements the result by saying, "the branch's selection process effectiveness has been limited due to absence of adequate information from concerned stakeholders and low data quality; added up with low experience of the risk management department."

The overall mean concerning the risk selection process and methods was below average $(\mathrm{M}=2.84, \mathrm{SD}=1.13)$. In general, the survey result was similar with previous studies (Getaneh, 2011, Kidist, 2016) that concluded there was weakness in applying the risk-based audit strategy in the study areas. Besides the information sources, effective risk selection process depends on availability of accurate \& timely data for risks to be addressed, appropriate analysis techniques applied to analyze the risk profile data, and the ability to facilitate feedback in to the compliance risk management system (OECD, 2006). These mean risk analysis techniques and risk selection team competence needs to be given due care.

\subsection{Types of Tax Audit Practiced and Sectors mostly audited}

The nature of audits conducted reflects the risks to be addressed and the desired audit coverage. The in-depth interview conducted with tax audit team leaders point out that risk based and service audit was practiced with the 
same tax auditors until the year 2018/19. However, following the major tax reforms undertaken in the revenue sector; most tax auditors were assigned to perform risk based tax audit cases and the left few tax auditors perform service tax audits like desk audits, de-registration audits (business closure audits), sale or transfer of company fixed assets and shares, dividend tax, etc.

From examination of the four years (2014/15-2018/19) annual performance report, it was observed that comprehensive audit (77.67\%) was mostly performed followed by desk audits $(13.56 \%)$. The performance of an investigation audit $(2.77 \%)$ and spot audit $(1.63 \%)$ was almost zero. Comprehensive audit stands first by number of files audited and number of revenue assessed (80.50\%) while investigation audit follows by additional tax assessment (18.36\%) even though less investigation audit files were conducted than desk audits. Spot audit was the least in relation to files audited and revenue assessed. Investigation audit yields the highest revenue per taxpayer because it was performed with intelligence input and information from third parties and indirect methods of auditing was mostly applied. The finding of tax types audited was reverse to ERCA (2010) Tax audit policy that recommends execution of 50-60\% spot or issue audit; and only 5-10\% comprehensive audit. However, the finding was similar with IMF (2015) study that shows lower income countries conduct more comprehensive audit $(53 \%)$, followed by issue oriented audit (28\%) and desk audits(19\%).

In 2011 budget year the branch office have audited 1006 risk based audit files and 939 service audits. In terms of revenue yield, the branch office has assessed 2.03 billion birr from risk based tax audit practices, and only 85.39 million birr from service audits. This means the branch have assessed 1.99 million birr on average per each risk based audit while assessed only 0.090 million birr from service audits. Similarly, the branch performed 108\% of the files and $433 \%$ in revenue collection. This best performance was mainly due to separating risk based tax audit practice from service audits (2018/19 Annual performance report). IMF (2015) stated, "Audit which has a key deterrence role in promoting compliance, is most effective when risk based" indicating the branch office focus on risk based audits.

To elaborate the findings more, 135 risk based tax audit reports were selected by multi stage sampling technique from the audited reports of the year 2014/15 to 2018/19. Accordingly, the branch office audited merchandising (31.11\%) followed by service $(30.37 \%)$. The findings are similar to that of Getaneh(2011) and inconsistent with the study conducted by Solomon(2019) in LTO that showed more selection of Manufacturing sector. Furthermore, since the study area is small taxpayers branch office, most taxpayer could be involved in businesses that require low initial capital like merchandising and service than manufacturing and construction. The study showed that all the sampled construction sector reports have assessed for additional profit while only $51.22 \%$ of the service sector was assessed for additional profit tax.

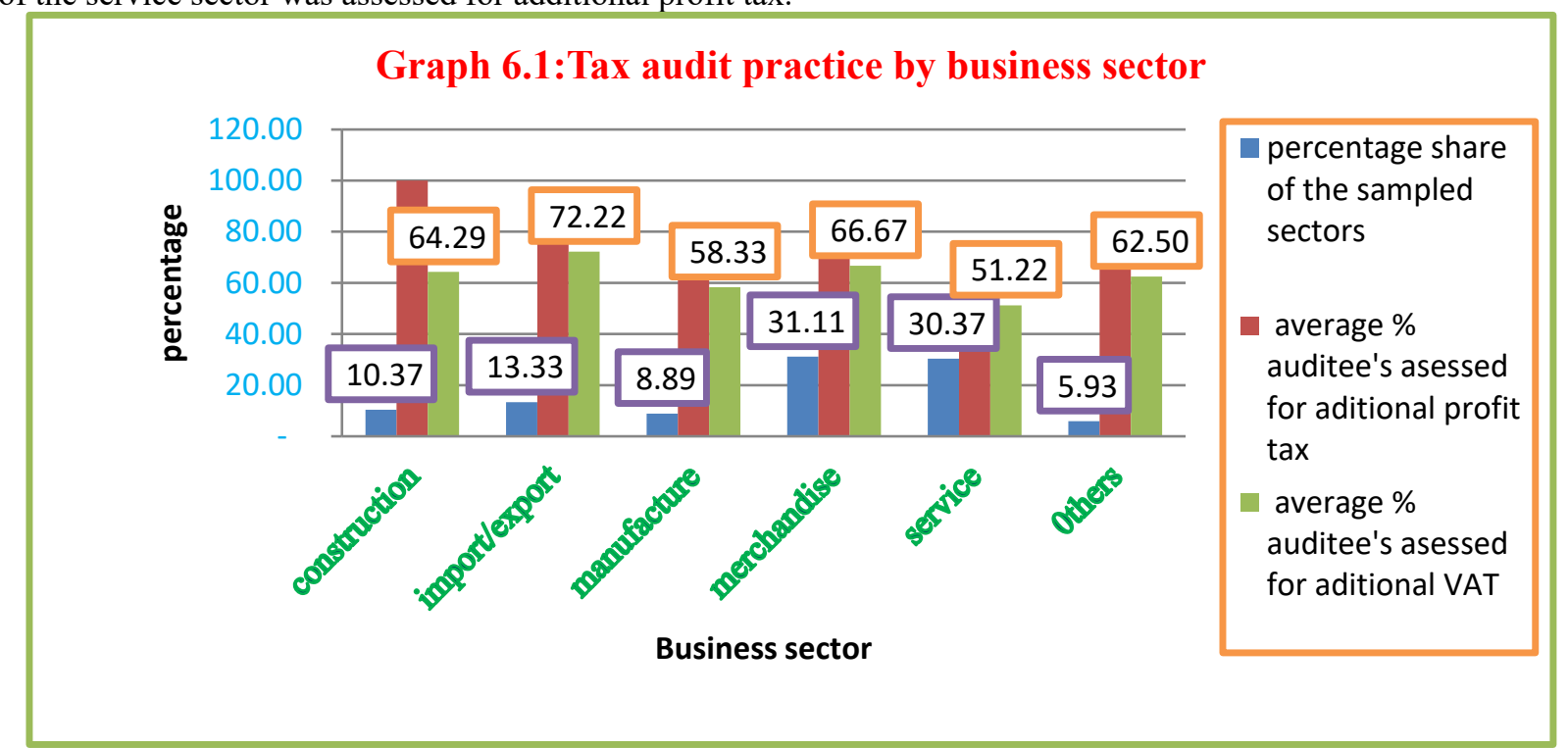

Source: compiled by the researcher from annual performance report of W/A/A/S/T/P/B/O, 2020

On the other hand, import/export sector was mostly assessed for additional VAT $(72.22 \%)$ while service sector was the least sector assessed for additional VAT $(51.22 \%)$. On average $80.20 \%$ of the sampled taxpayers were assessed for additional profit-tax and $62.54 \%$ were assessed for VAT. These shows construction sector was the most noncompliant business sector with tax laws indicating the branch office should focus on construction sector to assess additional revenue and should give priority to raise tax awareness for the business sector. Further, the study indicated service sector is the least assessed for VAT and profit Tax.

With regards to average total additional tax assessed per audited taxpayer (excluding penalty and interest); manufacturing sector stands first with br. $708,146.87$ followed by construction sector with br. 689,557.22 while; 
merchandise sector have less additional tax assessments of br.368,848.01. On average, each audited taxpayer was assessed for additional 507,321.46 br. These show reality that manufacturing sector is requires high initial capital, more complicated, with high transaction, complex costing, and complex accountancy system.

\section{CONCLUSION AND RECOMMENDATIONS}

The risk based tax audit effectiveness starts at having adequate audit resources and good risk criteria. The study indicated that the tax audit functions have adequate material resource but faced problem in having adequate IT infrastructures, and audit work was not usually supported by intelligence and third party information. Besides, there are no tax auditors' competency assessments and no well-established strategies that could make tax Auditors competent and effective on their job on continuous bases. Further, the risk selection criteria are similar for all branches irrespective of their taxpayer's characteristics and some of the criteria's are irrelevant for the branch. Interestingly, most of the tax auditors and team leader's believe the branch is not effective in selecting high-risk and non-compliant taxpayers due to low experience of the risk selection team, lack of quality data, lack of taxpayers post audit compliance review and prioritizing revenue than tax compliance.

The study result shows comprehensive audit stands first by number of files audited $(77.67 \%)$ and number of revenue assessed $(80.50 \%)$ while investigation audit follows by additional tax assessment $(18.36 \%)$. The audit practice was focused on merchandising sector $(31.11 \%)$ and, on average $80.20 \%$ of the sampled taxpayers was assessed for additional profit tax while $62.54 \%$ were assessed for VAT.

\section{Recommendations}

1. To enhance tax auditor's competence and audit performance, the team leaders would report challenging issues and exemplary cases solved in the team, and the process owner in collaboration with competent tax audit team leaders select important cases and present for discussion and experience sharing during the first week of the month for few hours. Team leaders, one-senior, one auditor, and a junior auditor could attend the meeting and further discuss on the subject as a team next day. Besides, the ministry of revenue should fund, monthly knowledge enhancement seminars on different selected topics and each audit team should take over the seminar that even creates chance of cooperation, competitiveness, and search for knowledge.

2. The $\mathrm{W} / \mathrm{A} / \mathrm{A} / \mathrm{S} / \mathrm{T} / \mathrm{B} / \mathrm{O}$ should use full risk-based audit selection strategy that protects and rewards taxpayer compliance and deploys the available resource against the non-compliant. Tax payers overall risk level should be prioritized during risk selection and audit cases assignment.

3. Information Technology should be upgraded in a timely manner to gather important taxpayer's information and effectively select risky taxpayers and encourage all employees to use computerized auditing techniques.

4. The Ministry of Revenue should apply different risk criteria for LTO, MTO, and STO, and should revise some of the risk criteria according to the changing economic situation of the country.

5. Having inadequate audit resources, the spot (issue) audit should be widely applied to increase the audit coverage, and education type audits should be implemented to improve taxpayers' awareness. Further, mechanisms should be implemented to perform audit activity based on intelligence input and third part information.

6. Government should give attention to reform of the revenue administration to enable effusive risk based practice that is technology based and capable to keep up with the increasing sophistication of business activity and tax evasion schemes.

\section{References}

African Economic Outlook (2019). Macroeconomic performance and prospects: African Development Bank.

Belay T. (2018). Assessment of Tax Audit Practice and It's Challenges: The Case of Adama Revenues And Customs Office, Master's Thesis. St. Mary's University, Addis Ababa, Ethiopia.

Biber, E. (2010). Revenue Administration: Taxpayer Audit-Development of Effective Plans: International Monetary Fund-Fiscal Affairs Department, Washington, DC.

Bird, Richard M. (2008).Tax Challenges Facing Developing Countries, Working Paper Series, IIB Paper No. 12 , Institute for International Business, Rodman School of Management,

University of Toronto, Canada.

Birskyte Liucija. 2013. Effects of Tax Auditing: Does the Deterrent Deter? Research Journal of Economics, Business and ICT 8:1.

Clement O, Stephen O. and Festus S. (2018). Tax audit and tax productivity in Lagos state, Nigeria, Department of Accounting, Faculty of Management Sciences, Ekiti State University, Ado-Ekiti, Nigeria, www.emeraldinsight.com/2443-4175.htm.

Cepheus Research\& Analytics (2019), Ethiopia's Recent Fiscal performance: A data Pack and Some Observations 
Ethiopia's Recent Fiscal Performance:

Drogalas G, Ioannis S, Dimitra D and Ioannis D (2015. Tax audit effectiveness in Greek firms: Tax auditors perceptions, Journal of Accounting and Taxation, http://www.academicjournals.org/JAT, Vol. 7(7), pp. 123130.

Das-Gupta A, Estrada. B, and Park D.(2016), Measuring Tax Administration Effectiveness and its Impact on Tax Revenue, EGC Report No: 2016/01, Economic Growth Centre, NTU.

EC(2006). Compliance Risk Management Guide for tax Administrations, Fiscals Risk Management Platform Group, the European Commission's Taxation and Customs Union Directorate General, version 1.02, February 2006, European Union.

Ephrem D. (2017). Tax Audit Practice in Ethiopia; Case of Federal Government. A Master's Thesis, St. Mary's University, Addis Ababa, Ethiopia.

ERCA (2010).Tax and PCA Audit Policy and Strategy, unpublished.

Federal Democratic Republic of Ethiopia (2016). Tax Administration, Proclamation number 983/2016, Federal Negarit Gazetta, Addis Ababa, Ethiopia.

Ghafoor.R, Furqan.F \& Aslam.M. (2011). Impact of Training and Development on Organizational Performance, Global Journal of Management and Business Research, Volume 11.

Getaneh, M. (2011).Tax Audit Practice in Ethiopia; Case of Federal Government.Masters Thesis, Addis Ababa University: Addis Ababa, Ethiopia.

IMF (2015), Current Challenges In Revenue Mobilization: Improving Tax Compliance, International Monetary Fund, Washington, D.C.

Kidist, T. (2016), Tax Audit Practice in Ethiopian Revenue and Customs Authority: Case of Addis Ketema Sub City.A Maters Thesis, St. Mary's University, Addis Ababa, Ethiopia.

Kircher, E. E. (2008). Enforced versus Voluntary Tax Compliance: The Slippery Framework. Journal of Economic Psychology, 29(2), $210-225$.

Ligomeka W. (2019). Assessing the Performance of African Tax Administrations: A Malawian Puzzle, African Tax Administration Paper 14, the International Centre for Tax and Development at the Institute of Development Studies, Brighton BN1 9RE, UK

Marshall, C. and Pomeranz,D(2013), Randomized Tax Enforcement Messages A Policy Tool for Improving Audit Strategies.

Mekonnen B. (2017), Challenges of Tax Audit Administration in Addis Ababa: evidence from Small Tax payer Branches; Addis Ababa: Master's Thesis, St. Mary’s University, Addis Ababa, Ethiopia.

Ministry of Revenue of Ethiopia (2019), Tax Audit Manual (unpublished).

Muhammad, Izlawanie(2013). Managing Mixed Responsibilities: A Grounded Theory of Malaysian Tax Auditors' Dispute Resolution Behavior in Audit Settlement: A Thesis in Fulfillment of The Requirements For the Degree of Doctor of Philosophy, School of Taxation And Business Law, The University of New South Wales, Australia.

Mukhtar Abdi Elmi et al (2015). International Journal of Business Management and Economic Research (IJBMER), Vol 6(6), 380-399

Neway, Gobachew, Kenenisa, L. Debela and Woldemicael, Shibiru( 2018). Determinants of Tax Revenue in Ethiopia. Economics. Vol. 6, No. 1, 2018, pp. 58-64. doi: 10.11648/j.eco.20170606.11,http://www.sciencepublishinggroup.com/j/eco.

Ngiu, Y. (2010). Tax Audit impact on voluntary compliance. Unpublished, Munich Personal RePEc Archive.

OECD (2006), Strengthening Tax Audit Capabilities: General Principles and Approaches, Information note, October 2006, Tax Administration Compliance Sub-group, available at $<$ http://www.oecd.org/dataoecd/46/18/37589900.pdf>, accessed on March 2020.

Solomon S. (2019). Perception of Tax Audit Practice: Evidence From Ethiopian Revenue and Customs Authority Large Tax Payers Office (LTO); Master's Thesis, Addis Ababa University: A.A, Ethiopia

Tesfaye, B. (2018),tax audit in Oromia Revenue Authority: Practices and Challenges, Addis Ababa: A Thesis, Addis Ababa University: Addis Ababa, Ethiopia

UNDP (2016), Working Paper on Performance and Prospects of Tax Collection in Ethiopia, www.et.undp.org

World Bank (2011), Risk based tax audits: Approaches and Country Experiences/World bank, Washington DC, USA.

Yesegat, W (2008), Value added tax withholding in Ethiopia: Implications for revenue performance and refund, paper presented at a symposium on VAT in developing countries: Policy, law and practice, Pretoria, South Africa, 18-21. 